\title{
SHAFTESBURY AS A POPPERIAN: CRITICAL RATIONALISM BEFORE ITS TIME? PART II
}

Keywords: humor, critical rationalism, Shaftesbury

Słowa kluczowe: humor, krytyczny racjonlizm, Shaftesbury

\section{Humor as Effective Criticism}

Shaftesbury maintains that ridicule or raillery should be applied to the inner philosophic life's soliloquy, as well as to philosophic conversation and writing. In the soliloquy of the inner life, ridicule's specific aim is to help form a balanced and harmonious character by deflating the passions and curing the melancholy that gives rise to unchecked enthusiasm. When referring to ridicule as a tool used in inner dialogue, Shaftesbury sometimes uses the word "humor." The character formed through soliloquy is both mirrored and further educated through philosophic conversation and writing by using ridicule, now referred to as "wit and humor." In accordance with $18^{\text {th }}$ century thought and practice, Shaftesbury does not clearly differentiate between wit and humor (Knox, 1961, p. 189). Humor, however, as distinguished from good humor, acquires for Shaftesbury the modern meaning of sympathetic yet critical laughter.

* Lydia Amir - College of Management Academic Studies, Rishon LeZion, Israel. E-mail: lydamir@colman.ac.il. 
Humor serves as a test of truth through the sociability of dialogue, whether as soliloquy, philosophic conversation or philosophic writing. Humor's role in soliloquy is to restrain enthusiasm's excesses, thereby opening the way to achieving a balanced character - the goal of the Shaftesburean good life. Together with wit, humor's role in philosophic conversation and writing is to further moral education through the combination of sociability and rationality. By challenging the melancholy of solitary reason, humor exchanges life-denying solitude for life-promoting good humor. I suggest clarifying the relation between humor and enthusiasm, the role of humor in soliloquy, and the roles of wit and humor within philosophic conversation and writing.

\section{Humor and Enthusiasm}

Shaftesbury's uniqueness lies in establishing a significant new alliance between two human characteristics: humor and enthusiasm. Human nature contains the principle of its change, and is thus characterized differently in various ancient civilizations as well as in modern cultures. Human nature is defined by movement that enables a dynamic alliance between enthusiasm and humor. The moralist, according to Shaftesbury, is sensible of the rhythm of subjectivity that spreads and checks itself, switching from exaltation to self-criticism "like a diastole and a systole of the soul," to use Jean-Paul Larthomas' analogy (Larthomas, 1986, p. 38; my translation). Within this rhythm, laughter is a sudden degradation, a sudden reduction of value to nothing or almost nothing. Because the soul aspires to heights, this reduction is followed by a new height of emotion. This rhythm should be controlled by defining its limits, that is, its "inward numbers and proportions" (Misc., III, ii, CR II, p. 270) ${ }^{1}$, and by taking into consideration the characteristics of the culture in which one lives.

1 The references to Shaftesbury's works correspond to the following abbreviations: CR: Characteristics of Men, Manners, Opinions, Times, etc., ed. John M. Robertson, in two volumes, 1963; CR3: Characteristics of Men, Manners, Opinions, Times, etc., $6^{\text {th }}$ edition, corrected, in three volumes, 1737; Essay: Sensus Communis, an Essthe Freedom of Wit and Humour; Inquiry: Inquiry Concerning Virtue or Merit; Letter: Letter Concerning Enthusiasm; Life: The Life, Unpublished Letters, and Philosophical Regimen of Anthony, Earl of Shaftesbury; Misc.: Miscellaneous Reflections on the Preceding Treatises, and other Critical Subjects; Moralists: The Moralists, a Philosophical 


\section{Humor in Inner Dialogue}

Humor is a tool in the service of reason whose purpose is to help the individual develop the appropriate character. Through humor, the self apostrophizes itself, that is, holds a counter-discourse with itself, thereby enabling the division required for dialogue in the inner philosophic life. As for Shaftesbury the essence of philosophy lies in self-creation and self-transformation, the role he allots to humor in the inner life makes it indispensable for philosophy as he understands it. Indeed, he reads the Roman Stoics as guides to the practice of self-formation, and both in his notebooks and in his published works he describes a therapeutic role for philosophy. In Soliloquy, for example, philosophy aims to "teach us our-selves, keep us the self-same persons, and so regulate our governing fancies, passions, and humours, as to make it comprehensible to our-selves, and knowable by other features than those of a bare countenance" (Soliloquy, III, i; CR I, p. 184). Similarly, in Miscellaneous Reflections, philosophy is defined as "mastership in life and manners" (Misc., III, i; CR II, p. 254), a discursive interpretation of philosophy that shaped Shaftesbury's notion of philosophy as public discourse. Since the aim of all moral reflection is to form the moral self, ethical insight without experiential implementation is sterile. Forming the moral self involves prying the autonomous self from its adhesion to society. This is the goal of Shaftesbury's Characteristics as a whole.

Shaftesbury's aim is to discover how we may form that which in the polite world is recognized as good taste. Philosophy as "the study of inward numbers and proportions" leads the mind to freedom and independence:

By knowing itself and its own proper powers and virtues $[\ldots]$ it sees its hindrances and obstructions, and finds they are wholly from itself, and from opinions wrong conceived. The more it conquers in this respect $[\ldots]$ the more it is its own master, feels its own natural liberty, and congratulates with itself on its own advancement and prosperity. (Misc., IV, i; CR II, p. 282)

This is the meaning of inward proportion and regularity of affection (Misc., IV, ii; CR II, p. 290), for "'tis we ourselves create and form our

Rhapsody; P.R.O.: The Shaftesbury Papers in the Public Record Office in at Kew, Surrey; Soliloquy: Soliloquy, or Advice to an Author. 
taste. If we resolve to have it just, 'tis in our power" (Misc., III, ii; CR II, p. 271-272).

To form one's taste demands courage and the will to undertake a radical inward transformation (Misc., IV, i; CR II, p. 282). "The narrowest of all conversations," soliloquy, or self-discourse, is the means for this end. Nonetheless it is "wholly impracticable without a previous commerce with the world; and the larger this commerce is, the more practical and improving the other [...] is likely to prove" (Misc., III, i; CR II, p. 252). Given that the relation to fellow human beings cannot be dissociated from the relation to oneself, the dialogue as defined by Shaftesbury corresponds to the soliloquy or conversation with oneself in the following sense: the soliloquy is possible only if it is conceived as a dialogue, that is, only if the self divides in two. Humor enables such division because humor is a doubling of and a distancing from oneself. It is not only a critical disposition towards others, but also towards oneself. Laughter is simply the social expression of the development of the critical spirit. Since there is no separation between external social criticism and internal criticism with respect to humor for Shaftesbury, laughter is seen as an exchange with others as well as with oneself.

Shaftesbury re-describes the Delphic inscription "Know thyself" as an exhortation to soliloquy: "This was, among the ancients, that celebrated Delphic inscription, 'Recognize yourself!', which was as much as to say, 'Divide yourself!' or “Be two!” (Soliloquy, i, 2; CR I, p. 113). Furthermore, Shaftesbury maintains that human beings naturally feel a division within themselves between a better self - the "true and natural self" - and a worst self (Soliloquy, iii, 1; CR I, p. 183). Laughter serves as a criticism of the worst self. This is the basis of Shaftesbury's method of inward dialogue or "soliloquy," which he regards as an essential means of self-knowledge and self-mastery.

The goal of the inward dialogue is to educate the passions through reason in order to change habits. The practice the Stoics use is to "set a contrary habit to counteract this habit." Echoing Epictetus, Shaftesbury asserts that "the best Practice and Exercise is to go by contraryes, just in the teeth of Temper, just opposite of Humour." As the human temper is suspended between poles of expectation and dejection, the solution of such pendular movements is an object of training. Moreover, the very polarity of the emotions is the basis of a dialectical method. The principle of Shaftesbury's philosophical regimen as described in his Exercises is a deliberate self-contra- 
riness. Lawrence Klein explains that "the over-florid emotional palette had to be countered by the self-conscious pursuit of pallor and grayness, and vice versa" (Klein, 1994, p. 86). In this respect, Shaftesburean self-directed humor functions by apostrophizing fancies with inward exclamations of "Ridiculous!" Shaftesbury's originality lies in his use of humor as a means of deliberate self-contrariness with the purpose of deflating the emotions, especially the passion of enthusiasm.

\section{Humor and Wit in Philosophic Conversation}

Shaftesbury insists that soliloquy presupposes conversation and a previous commerce with the world: "The larger this commerce is, the more practicable and improving the other [soliloquy or self-discourse] [...] is likely to prove" (Misc., III, 1; CR II, p. 252). Philosophic conversation, which mirrors the character that is formed inwardly, presupposes the inner dialogue of the philosophic life.

Quoting Horace to the effect that "a jest often decides weighty matters better and more forcibly than can asperity" (Horace, Satires, I, x, 14, 15.11), Shaftesbury suggests that reason is well served by a lighter conversation:

If rational discourses (especially those of a deeper speculation) have lost their credit, and are in disgrace because of their formality; there is reason for more allowance in the way of humour and gaiety. An easier method of treating these subjects will make them more agreeable and familiar. (Essay, i, 6; CR I, p. 54)

By being critical, a humorous conversation undermines unwarranted assertion; by being open-ended, it illuminates various aspects of the subject at hand; and by being amiable, it encourages further discussion. Such a conversation has other virtues as well. For one thing, it is free:

It is the habit alone of reasoning, which can make a reasoner. And men can never be better invited to the habit, than when they find pleasure in it. A freedom of raillery, a liberty in decent language to question every thing, and an allowance or unraveling or refuting any argument, without offence to the arguer, are the only terms which can render such speculative conversations any way agreeable. (Essay, i, 4; CR I, p. 49) 
Ideal conversation is a moral framework for public interchange, according to Shaftesbury, since conversation of this sort embodies the norms of freedom, equality, activity, and pleasure. In allowing individuals to become more rational and more autonomous, it fits into an emancipatory program. At the same time it is a model of intellectually productive discourse since it provides the best conditions for the advancement of reason.

Imposing silence on an audience by making them unwilling listeners is an undesired alternative to ideal conversation, according to Shaftesbury. When one person monopolizes the conversation, dominance replaces equality, gravity replaces lightness, discomfort replaces pleasure, and dogmatism replaces skepticism. Reason is less efficiently served in the oratorical situation not only because criticism is silenced but also because auditors are more likely to be repelled than convinced (Essay, i, 4; CR I, p. 49-50).

Conversation requires reason and learning as well as playfulness and dalliance (Moralists, i, 1; CR II, p. 5-6). Instead of the prevalent forms of elite life, Philocles in The Moralists envisions other forms inspired by antiquity, where:

Reason and wit had their Academy, and underwent this trial; not in a formal way, apart from the world; but openly, among the better sort, and as an exercise of the genteeler kind. The greatest men were not ashamed to practice this, in the intervals of public affairs, in the highest stations and employments, and at the latest hour of their lives. (Moralists, i, 1; CR II, p. 9)

The sensus communis, according to Shaftesbury, develops the sort of wit and humor that ridicules justly and without offence: "For without wit and humor, reason can hardly have its proof or be distinguished." Shaftesbury recalls the formula of the sophist Gorgias Leontinus: "It was the saying of an ancient sage that 'humour was the only test of gravity, and gravity, of humour." "He adds that one should suspect a truth that cannot stand against raillery, and humor that is not tempered with gravity: "For a subject which would not bear raillery was suspicious, and a jest which would not bear a serious examination was certainly false wit" (Essay, i, 5; CR I, p. 52).

The more accurate translation of the passage from Aristotle's Rhetoric reads: "Gorgias said it was necessary to spoil the seriousness of opponents by jest and their jest by seriousness" (Rhetoric 3.18.7). Shaftesbury transforms the sophist's rhetorical advice into a statement with philosophic import. This 
accords with his belief that eloquence and philosophy should converge. As we recall, "truth, it is supposed, may bear all lights, and one of those principal lights, or natural mediums, by which things are to be viewed, in order to a thorough recognition, is ridicule itself, or that manner of proof by which we discern whatever is liable to just raillery in any subject" (Essay, i, 1; CR I, p. 44). For Shaftesbury then, the object of conversation should lose its seriousness so that the wits may approach it freely, discuss it and evaluate its truth. Humor, thus, is policed and is therefore neither derision nor buffoonery. Liberty of tone, he claims, is nothing but the expression of the liberty of thought that is indispensable when approaching truth.

Because no subject, whether moral, political or religious, is important in itself, it is the enunciator's seriousness that is at stake and not that of the conversation. Laughter may appear to some as a sign of violence, but for Shaftesbury it is an indication of tolerance (Misc., III; CR II, p. 238-273). The amiable nature of humor does not follow from a principle of charity or external sociability, but is intrinsic to its operation. Railing against the declared importance of a truth changes the relation to the other. In attacking a principle, one is in danger of threatening the other's liberty of thought, and the discussion may degenerate into a battle of dogmas and, ultimately, of passions. Raillery, however, detaches truth from its passionate origin: both the other and oneself find or regain the capacity for free examination and thereby a possibility of concord, or at least a possibility of entering into an accord that is indispensable to conversation.

As Shaftesbury consistently repeats, the practice of humor presupposes mutuality (Essay, i, 1; CR I, 44; iv, 3; CR I, p. 97). The distance from oneself that humor creates opens a space for the examination of truth and enables conversation to unfold without any of the speakers appropriating or claiming authority. Therein lies humor's merit. Conversation is a social form in which liberties are tried and truths are proposed, corrected, and established through discussion. To prefer good humor over rigid formalism is to socialize the discourse, that is, to place oneself in the true condition of discourse. This is a rational task; it is the opposite of melancholic reasoning, which is the mark of a temperament that tends toward isolation. 


\section{Humor and Wit in Philosophic Writing}

Shaftesbury's intellectual project can be cast as a search for an adequate form of philosophy both as an introspective endeavor and a social activity. This search impacts the manner of writing philosophy as well:

In reality, however able or willing a man be to advise, it is no easy matter to make advice a free gift. For, to make a free gift indeed, there must be nothing in it which takes from another to add to ourselves. In all other respects, to give and to dispense is generosity and goodwill, but to bestow wisdom is to gain a mastery which cannot so easily be allowed us. Men willingly learn whatever else is taught them. They can bear a master in mathematics, in music or in any other science, but not in understanding and good sense. It is the hardest thing imaginable for an author not to appear assuming in this respect. (Soliloquy, i, 1; CR I, p. 103)

For advice to be accepted it should be proffered lightly (Soliloquy, i, 1; CR I, p. 104). Humor and wit provide the lightness and agility necessary for philosophy as moral education:

As grave however as morals are presumed in their own nature, I look upon it as an essential matter in their delivery to take now and then the natural air of pleasantry. The first morals which were ever delivered in the world were in parables, tales, or fables. And the latter and most consummate distributers of morals, in the very politest times, were great taletellers and retainers to honest Aesop. (Misc., IV, i; CR II, p. 283)

Humor frees both the reader and the author-the author becomes unassuming while the reader is free to appropriate the moral truth as she wishes.

The aim of using humor in philosophic writing is two-fold: first, to reach a larger public as did ancient philosophers in their exoteric writings in antiquity; and second, to encourage independent reflection in the reader. The writer's use of humor is self-effacing, thereby enabling the reader to engage in the inner work necessary for moral improvement.

The views of the Cynics and Roman Stoics on the role of humor within moral teaching are relevant to Shaftesbury's own view. The mixture of humor and popular philosophy was characteristic of Cynic literature. By the middle of the third century B.C., Cynicism had evolved a type of literature, the serio-comic (to spoudaiogeloion), that offered definite genres for the popular 
exposition of philosophy. By that time, both the Epicureans and the Stoics were prepared to popularize their teachings. The Stoics always used Cynic literary genres for their exoteric teachings. By "speaking the truth, laughingly" (Ridendo dicere verum), the Stoics promoted the importance of taking oneself less seriously than is the custom. To that end, they recommended a style based on a mixture of humor and seriousness that proposed laughter as a means to assuming a more balanced perspective of serious matters.

Shaftesbury recommends wit and humor in philosophic writing for the benefit of the author as well. The full title of his work Advice to an Author is preceded by Soliloquy, thereby drawing attention to the melancholy of the solitary creative writer (Soliloquy, iii, 2; CR I, p. 197-212). To fight melancholy the author must transcend his solitude. The very act of writing should be an exercise in sociability: wit is assigned a primary role, accompanied by humor whose aim is to erode all that is life-denying.

Humor plays a crucial role throughout Shaftesbury's discussion of philosophy in all its varied forms, whether soliloquy, conversation, or writing. A method for challenging all forms of irrationality, humor denotes a fundamental capacity for the apprehension of the true, the beautiful, and the good. Humor is a liberating tool freeing us from patterns of action and thought that are ultimately life-destroying. It is an essential element in the formation of character and the sociability necessary for common sense. Without humor the virtue and happiness constituting the Shaftesburean good life are unattainable.

In order to assess Shaftesbury's view that criticism to be effective should be humorous, it is important to clarify its relation to Shaftesbury's conception of truth. Independent of the view of "ridicule, the test of truth," Shaftesbury's view of humorous criticism is still premised on the lesser assumption that truth cannot be marred by humor. Because truth, as Shaftesbury asserts, can withstand "all lights," including that of ridicule, humorous criticism should not to be feared. To be effective, however, criticism should not be true, only humorous.

Criticism is effective when humorous, first, because criticism is most helpful when specific, and humor is always specific. Brand Blanshard reminds us that "most of us are incapable of moving freely in the world of pure universals... we must touch ground again pretty often to renew our strength and courage...most men's minds are so constituted that they have to think by means of examples" (Blanshard, 1954, p. 132). Moreover, humor 
reduces anxiety, alerts the mind, and enhances creativity as well as liberty of thought - all processes that ameliorate reasoning and open-mindedness. Furthermore, humor itself enables cognitive change. Because in humor our perception becomes more attentive, the sensible world takes on a new value, and its image becomes clearer under the humorist's gaze. His gaze acquires the acuity of a new vision; and as all the senses participate in this change, it is the whole of our perception that is modified (Cazamien, 1952, p. 107). John Lippitt has recently explained how the comic is helpful in moral transformation (Lippitt, 2000, p. 159).

The view that effective criticism must be humorous has been in practice since the exoteric moral teachings of the Ancient philosophers revived by Renaissance and Modern philosophers. Philosophers, such as Plato, criticize ignorance; with the Stoics, they disparage the tragic view of life, attacking common morality and religion (the pre-Socratic Xenophanes, the Cynics, the Peripatetic Theophrastus, the Hellenistic skeptical philosopher Timon of Phlius, the Platonic philosopher Lucius Apuleius, the Renaissance philosophers Erasmus and Thomas More, and the modern philosophers Pascal and Voltaire, among others); and they scorn "academic" philosophy for neglecting the moral or existential task at hand (i.e., the Cynics, and after Shaftesbury, Kierkegaard and Nietzsche).

For Shaftesbury, all philosophy is exoteric moral teaching. Hence, he revitalizes the Ancient philosophers' device for exoteric moral teaching and defends the necessity of its use for all the forms of his philosophical expression, from inner dialogue to philosophic conversation and writing. Huston Smith notes that most people are exoterics, in that feeling or experience is more important to them than thought (Smith, 2001, p. 259), and Brand Blanshard reminds the philosopher to be careful with the beliefs he is attacking, because they are intertwined with hopes and fears (Blanshard, 1954, p. 131-132). When philosophy is not conceived as an esoteric activity, then, humor can be helpful in furthering philosophy's critical aims.

While not original in itself, the view that effective criticism should be humorous innovates when it is implemented in inner dialogue and the reciprocity of conversation, rather than in the one-sidedness of philosophic writing or teaching. In inner dialogue, the role of humor is disciplinarian: it forms and corrects one's judgment by reducing the arrogant seriousness and false grandeur of the self. It is a negative instruction that aims at self-knowledge and self-formation through awareness of the limits of self-expansion. 
In conversation, the inter-subjective condition of the comic presupposes a commonality of both feeling and judging (implicitly) things, situations, and ideas. We have to temper this spontaneous judgment by another form of reflexive consciousness of common sense, which is called taste or tact. But when this is done, judgment equals good sense, and laughing, as judging, is reason working to diminish the excesses of sensibility. Laughter produces a derisory awareness of the subjective when the subjective is confronted by an authentic rational judgment. "The things themselves," explains Ernst Cassirer, "upon seeing their images as mirrored by this elemental power of the intellect, recognize, so to speak, their true inner proportion and return to it. In so doing they regain their appointed place in reality" (Cassirer, 1953, p. 179).

We must introduce judgment in the initial affective dynamic of laughter by confronting laughter with sense. With humor, the notion of sense takes root in the exchange between persons, revealing in the process of communication the moment when sense vacillates. The philosophic value of humor lies in its being a privileged instrument of sense, because humor is a vacillation of sense that confirms or refutes within the coherence of the whole that which one believes. Laughter can be a criterion of sense because it incorporates a theory of sense that enables the interrogation of human practices. Conversation is the par excellence locus of humorous expression because through a succession of questions and answers conversation enables humor to exert a tight criticism of sense in the name of a pre-existing common sense. This is why humor-the criticism of sense by laughter - provides a foundation for philosophical criticism. In the Essay, laughter as humor is an instrument of reason, making the exercise of humor a social art that is both sensible and intelligent. As a measured and measuring laughter, humor, thus, is an expression of the philosophical orientation of the art of conversation.

Shaftesbury also innovates in singling out enthusiasm as the main human characteristic humor should criticize. The aim of the association between humor and enthusiasm is to make enthusiasm creative rather than visionary. The Enlightenment and the Aufklärung begin with a fundamental conflicting attitude towards enthusiasm, one that seeks to eliminate the irrationality of superstition without drying up the fountain of its fervor. Kant and other thinkers entrust English humor with the important mission of resolving this conflict. Shaftesburean humor is the sign of the awareness of finitude. Humor is the acceptance of an inward measure, of an equilibrium 
that welcomes the inward truth of every situation, even if and maybe because, understanding does not always comprehend the why and how. Humor, for Shaftesbury, is thus the positive expression of the awareness of our limits, both as intelligent and sensible beings.

Shaftesbury's view of humor is innovative, especially in its connection between enthusiasm and humor and the use of the former in soliloquy. He enunciates the modern view of humor, enabling us to adopt it today in philosophical soliloquy, conversation, and writing for the benefit of the philosopher, his interlocutors, and his readers.

\section{Humor as the Mark of Rationality}

Shaftesbury's view that humor is the mark of rationality complements his view of effective criticism as humorous. First, Shaftesbury equates rationality with critical dialogue; by further equating criticism with humor, however, Shaftesbury makes humor the mark of rationality.

Reason, for Shaftesbury, is dialogical and rhetorical. Knowledge is part of social life and, thus, reason depends upon laying down the conditions for reasonable social conduct. Truth about human matters is not discovered through abstract philosophy, but through the rigors of conversation. Reason is directly sociable, a factor of morality and community. Conversation establishes communication, which is necessarily grounded in community. Conversation is the model of communication of all philosophic truth and the ability to converse is one of the most defining characteristics of the person who uses reason. All discourse that aims at rationality or truth is inspired by the dialogical polyphonic model of conversation. Thought exists only when it puts passion into movement; it is best advanced through conversation, whose characteristics are mobility, unpredictability, and dramatization. Conversation must be aporetic, free, and open-minded to fulfill its critical function. For Shaftesbury, reason does not reason, but converses, and free conversation is aporetic.

In this matter, as in other matters, Shaftesbury draws his inspiration from the ancient Greek and Roman philosophers who used dialogue to discuss philosophic questions. The characters of Plato's dialogues, and especially Xenophon's, test each other's positions with wit and humor, Shaftesbury believes, seeking to arrive at ideas that can withstand the criticism of 
ridicule. This is the means by which reason should operate, because "without wit and humour, reason can hardly have its proof or be distinguished" (Essay, i, 5; CR I, p. 52). Shaftesbury equates criticism with humor, as humor is a vacillation of sense that confirms or refutes that which one believes within the coherence of the whole. Humor is a criticism of sense by laughter, which constitutes the premises of philosophical criticism, as we have seen in the previous discussion of humor as effective criticism.

By equating criticism with rational thought, and humor with criticism, Shaftesbury makes humor the mark of rationality. In his equation of criticism with rational thought, I suggest that Shaftesbury anticipates Karl Popper's critical rationalism.

The distinguished philosopher of science is best known for his thesis that science does not, and cannot, verify its theories. Science makes progress by proposing bold conjectures in response to problems, which are then subject to a sustained attempt at empirical refutation. To extend his theory that rationality consists of scientific research and methodology alone, Popper loosens his standard of rationality. Rejecting the older standard of rationality - proof - as too high, he views the standard for science - refutability - as also too high for the rationality that obtains outside science. Whereas earlier he has replaced justification with refutation, he now replaces refutation with criticism. Popper thereby creates a new philosophical perspective by generalizing his theory of scientific research. The name he gives to this extension is "critical rationalism." As a general methodology for solving problems or making progress, Popper describes critical rationalism in the introduction to his Conjectures and Refutations (1963), where he characterizes it briefly as the critical attitude. He also uses it to describe views he developed earlier, in The Open Society and Its Enemies (1962) and The Poverty of Historicism (1961), where he applied critical rationalism to problems of civilization.

As Popper puts it in The Logic of Scientific Discovery, "inter-subjective testing is merely a very important aspect of the more general idea of intersubjective criticism, or in other words, of the idea of mutual rational control by critical discussion" (Popper, 1959, p. 44, n. 1; see 1963, p. 193-200; 1972, p. 119, 243). Popper uses "rationalism" to denote "an attitude or readiness to listen to critical arguments and to learn from experience," of "admitting that I may be wrong and you may be right, and by an effort, we may get nearer to the truth" (Popper, 1962, II, p. 225). In a lecture given in 1960, rational discussion is characterized as a "critical discussion in search of mistakes with 
the serious purpose of eliminating as many of these mistakes as we can, in order to get nearer to the truth" (Popper, 1963, p. 229). In his autobiography Unended Quest, he gives criticism, in retrospect, the greatest weight. In The Open Society and Its Enemies, he reminds us that he has already argued "that one of the best sense of 'reason' and 'reasonabless' was openness to criticism" and suggests that the demand to "extend the critical attitude as far as possible might be called 'critical rationalism"” (Popper, 1974, p. 92). And in the introduction to The Myth of the Framework, he writes that "critical rationalism is a way of thinking and even a way of living. It's a faith in peace, in humanity, in tolerance, in modesty, in trying to learn from one's mistakes, and in the possibilities of critical discussion [...] [it is] an appeal to reason" (Popper, 1994, p. xiii).

Popper considers rationality as contrary to human nature's craving for security. He considers rationality "not a property of men" but "a task for men to achieve" (Keut, 2005, p. 134). Popper admits that there is a resistance to criticism or the elimination of errors, whose origin can be found in human nature, and which he designates as the "dogmatic" attitude. We are faced by a moral choice between irrationalism and rationalism, which can be prompted by criticizing irrationalism. Popper's critical rationalism "frankly admits its origin in an irrational decision" (Popper, 1962, II, p. 231), an "act of faith - ...faith in reason." After this original leap, as Herbert Keut explains, "rationality is developed only by criticism" (Keut, 2005, p. 239-240). Reason, like science, grows by ways of mutual criticism; the only possible way of "planning" its growth is to develop those institutions that safeguard the freedom of criticism, that is to say, the freedom of thought (Popper, 1962, II, p. 227). We not only owe our reason to others, but we can never excel others in our reasonabless in a way that would establish a claim to authority; authoritarianism and rationalism in our sense cannot be reconciled, since argument, which includes criticism and the art of listening to criticism, is the basis of reasonabless (Popper, 1962, II, p. 226). Thus, Popper's philosophy, although rejecting all forms of irrationalism, is a philosophy of tolerance (Popper, 1962, II, p. 238).

The distinction between dogmatic and critical thought is at the center of Popper's thought and appears as early as his $1927 \mathrm{Ph} . \mathrm{D}$. thesis "The Quest of Method in Cognitive Psychology": 
Free thinking ... is critical thinking - dogmatic thinking is unfree: By free thinking one can only mean thinking "without prejudices", that is, thinking which judges state of affairs, without presupposing the result ... of judging; critical thinking is also thinking guided by reasons; it is an active and spontaneous form of thinking, in contrast to dogmatic thinking, which does not touch the accepted (adopted) "judgement". (Popper, 1927, p. 10)

But how does one advance from dogmatic thinking to critical thinking? Popper has not written at length on education although scattered passages in the text and notes of The Open Society and its Enemies contain some interesting comments. Popper admits that educating involves "something like [a] romantic or aesthetic element" (1962, II, p. 276). By empathy, the child imitates the teacher's rationality. Popper's Ph.D. thesis on the psychology of thinking may shed light on this issue. Michel ter Hark (2004a, 2004b) has found that Popper subjected the childish phenomenon of dogmatic thinking to a detailed conceptual and empirical analysis resulting in a complex experience, the "experience of regularity" (Gesetzerlebnis), and consisting of three elementary experiences: attitude (Einstellung), discovery (Setzung), and standing by one's opinion (Festhalten). Children, according to the young Popper, expect regularities everywhere and seek to find them even where there are none. They typically adhere to their expectations even when inadequate and when they ought to accept their inadequacy. In many cases, the resistance to (critical) demands of modification prompts or is even the result of what he calls "the fear of the unfamiliar" and the need for assurance or certainty:

The fear of the unfamiliar, the feeling of displeasure, [more easily] crosses the threshold of consciousness than the feeling of pleasure, the pleasure about what is known, since repetitions numb the irritability. (Popper, 1927, p. 54) Popper maintains that the familiar, or habitual, typically does not catch one's attention, that the unknown or unfamiliar crosses more readily to the level of consciousness, and that this consciousness typically takes the form of fear or anxiety.

A superficial consideration of the concept of habit reveals how problematic it is to combine an education through habit with an education that conforms to the ideals of free thinking; for inherent in the concept of habit, Popper claims, is "a strong passive element, a moment of automatism, the loss 
of insightful, active thought and its replacement by 'automatic' association" (Popper, 1927, p. 11). These educational implications of the psychology of dogmatic thinking, however, receive no further treatment in Popper's thesis, thereby testifying to its unfinished character. Nor does Popper develop them in his philosophic writings, where he emphasizes the importance of dogmatic thinking as well as its difference from critical thinking without bridging the, two unless through criticism of dogmatic thought or by an act of faith followed by criticism's continual development of rationality.

Some of Shaftesbury's ideas can be recognized in Popper's critical rationalism. This is hardly surprising, as both the $18^{\text {th }}$ century philosopher and Popper are Socratics, and Popper's predilection for the Enlightenment is well attested. It is because Shaftesbury equates rationality with criticism that I consider him a precursor of critical rationalism. It is important to bear in mind that Shaftesbury's philosophy, no more than other Socratic views, however, cannot replace Popper's critical rationalism, because in contradistinction to others who recommend criticism, for Popper criticism is sufficient for rationalism. Moreover, Shaftesbury does not develop a theory of rationalism and certainly not a methodology for science. He advocates, rather, a form of enthusiasm whose purpose is to help us intuit the world as a harmonious, organic and congruent whole, thereby complementing reason with intuition.

None the less, Shaftesbury equates rationality with criticism. By taking the additional step of equating humor with criticism and thereby making humor the mark of rationality, Shaftesbury advances a view that is entirely original, with no precedents or followers. This view can be accepted as a better version of Karl Popper's thesis, that critical thinking is the very essence of rationality, because it takes into consideration the psychological resistance to criticism that Popper acknowledges but does not address.

Although gifted with a sense of humor, Popper would not have accepted the assistance humor affords in soothing one's fears and making criticism more palatable: for him, I am told, criticism was sacred and standards of clarity were imperative (Popper, 1962, II, p. 20). I do suggest, however, that the Shaftesburean use of humorous criticism can further our capacity for welcoming criticism; and as Shaftesbury equates rationality with criticism, we can summarize his view by saying that the right use of humor promotes rationality. Thus, Shaftesbury's proposal can be helpful to critical rationalists who are interested in promoting rationality as criticism. 
This is one more reason to pay attention to Shaftesbury's views on humor. Rarely has there been a thinker who has invested humor and ridicule with such a mighty task as represented by Shaftesbury's four tenets, namely, that ridicule is the test of truth, that humor and good humor have a habilitating function with regard to truth, that criticism must be humorous in order to be effective, and that humor is the mark of rationality. Shaftesbury is the first to attribute an important role to humor, ridicule and good humor within philosophy. Moreover, since the practice of reason is mainly a practice on oneself, and since true knowledge is self-knowledge and selfformation, the creation of a harmonious and virtuous character is the goal of the philosophical life - the good life as Shaftesbury conceives it. Humor has never been given a higher place within the good life: as a liberating, life-giving, and life-forming power of the soul, humor is constitutive of the Shaftesburean good life, for without humor, the good life cannot be attained nor maintained.

\section{References}

Aristotle (1970). The Rhetoric of Aristotle. Hildesheim: G. Olms.

Blanshard, B. (1954). Selections from On Philosophical Style. In: Philosophical Style (p. 123-43). Berel Lang.

Cassirer, E. (1953). The Platonic Renaissance in England. Trans. J.P. Pettegrove. Edinburgh: Thomas Nelson and Sons.

Hark, M. ter (2004a). Popper, Otto Selz, and the Rise of Evolutionary Epistemology. Cambridge: Cambridge University Press.

Hark, M. ter (2004b). The Psychology of Thinking, Animal Psychology, and the Young Karl Popper. Journal of the History of the Behavioral Sciences, 40 (4), 375-393.

Horace (1959). The Satires and Epistles of Horace. Chicago, IL: University of Chicago Press.

Keut, H. (2005). The Philosophy of Karl Popper. Cambridge: Cambridge University Press.

Klein, L.E. (1994). Shaftesbury and the Culture of Politics. Cambridge: Cambridge University Press.

Knox, N. (1961). The Word Irony and Its Context, 1500-1755. Durham: Duke University Press. 
Larthomas, J.-P. (1986). Humour et enthusiasme chez Lord Shaftesbury (1671-1713). Archives de philosophie, 49, 355-373.

Lippitt, J. (2000). Humor and Irony in Kierkegaard's Thought. New York, NY: Macmillan.

Popper, K.R. (1927). “Gewohnheit” und "Gesetzerlebnis”. In: der Erziehung: Eine pädagogisch-strukturpsychologische Monographie. Hoover Institute Archives. Karl Popper Papers, box 12, file 11.

Popper, K.R. (1959). The Logic of Scientific Discovery. London: Hutchinson.

Popper, K.R. (1961). The Poverty of Historicism. London: Routledge and Kegan Paul.

Popper, K.R. (1962). The Open Society and Its Enemies. 2 vols. London: Routledge and Kegan Paul.

Popper, K.R. (1963). Conjectures and Refutations: The Growth of Scientific Knowledge. London: Routledge and Kegan Paul. $5^{\text {th }}$ revised edition, 1989.

Popper, K.R. (1972). Objective Knowledge. Oxford: Oxford University Press.

Popper, K.R. (1994). The Myth of the Framework. London: Routledge.

Shaftesbury, A.A.C. (1963 [1900]). Characteristics of Men, Manners, Opinions, Times, etc. Gloucerster, MA: Peter Smith.

Shaftesbury, A.A.C. (1837). Characteristics of Men, Manners, Opinions, Times, etc. $6^{\text {th }}$ edition. 3 vols, corrected. London: James Purser.

Shaftesbury, A.A.C. (1992 [1900]). The Life, Unpublished Letters, and Philosophical Regimen of Anthony, Earl of Shaftesbury, London-New York: Swan Sonnenschein, Macmillan.

Shaftesbury, A.A.C (1698-1712). Askêmata, two notebooks. The Shaftesbury Papers in the Public Record Office in London (P.R.O.), 30/24/27/10.

Shaftesbury, A.A.C. (1706). Pathologia sive Explicatio Affectum Humanorum. The Shaftesbury Papers in the Public Record Office in London (P.R.O.), $30 / 24 / 26 / 7$.

Smith, H. (2001). The Meaning of Life in the World's Religions. In: J. Runzo, N. Martin (eds.), The Meaning of Life in the World Religions (p. 255-268). Oxford: Oneworld. 


\section{SHAFTESBURY AS A POPPERIAN: CRITICAL RATIONALISM BEFORE ITS TIME? PART II}

\section{Summary}

Shaftesbury has assigned humor an unparalleled role within philosophy, which may be encapsulated in the following tenets: (1) ridicule is the test of truth; (2) humor and good humor have a habilitating function with regard to truth; (3) the most effective criticism is humorous; and (4) humor is the mark of rationality. In the present article, I introduce Shaftesbury's views on ridicule, good humor and humor in order to assess both the originality and viability of Shaftesbury's contribution. I argue, first, that Shaftesbury's views on ridicule as a test of truth and on good-humor as habilitating truth are thoroughly original, but cannot be implemented without adhering to his metaphysics and epistemology. Second, Shaftesbury's views on humor are only partially original, though these can be implemented independently of metaphysical and epistemological assumptions for the greatest benefit of philosophers in general and critical rationalists in particular. I conclude that not only does Shaftesbury anticipate the view that critical thinking is the core of rationality, the main principle of the view known as critical rationalism associated with the renown $20^{\text {th }}$ century philosopher of science and social philosopher, Karl Popper, but he also offers a viable means to enhance criticism as rationality by taking into consideration the psychological resistance to criticism that Popper acknowledges but refuses to address. 